\title{
Variation of Rain Water Quality with Storage Time for Different Coloured Storage Containers
}

\section{*OLADELE, EM; OJO, OM; ADEWUYI, AS}

\author{
Department of Civil Engineering, Federal University of Technology, Akure, Nigeria
}

*Corresponding Author Email: rahlpierre82@gmail.com

\begin{abstract}
It is very important to evaluate the quality of rain water collected and stored in cisterns and storage tanks. In this study, rainwater quality analysis was carried out on samples collected from an experimental set -up at the School of Engineering and Engineering Technology of the Federal University of Technology, Akure, Nigeria. The physio-chemical and bacteriological characteristics of rainwater collected and stored using four different coloured containers under outdoor and indoor conditions were analyzed and the results compared with World Health Organization (WHO) standard for potable water. The results of the physio-chemical analysis revealed that the colour, turbidity, total dissolved solids (TDS), phosphate, sulphate, iron and copper of all the rainwater samples fell within WHO acceptable standards for potable water. The $\mathrm{pH}$ of the harvested rainwater of the samples ranged from $5.34-$ $6.73 \mathrm{mg} / \mathrm{l}$ for the indoor stored rainwater samples and $5.28-6.59 \mathrm{mg} / \mathrm{l}$ for the outdoor stored samples. The $\mathrm{pH}$ of the water samples did not fall with WHO permissible limit of 6.5 to 8.5. The Nitrate content of the water samples also did not fall within WHO permissible limit. Similarly, the total coliform count did not conform to WHO standard for potable water. Based on the results obtained from this study, it is recommended that harvested rainwater be treated to kill contaminating microorganisms and to reduce the health risks associated with its consumption.
\end{abstract}

DOI:https://dx.doi.org/10.4314/jasem.v25i9.22

Copyright: Copyright (C) 2021 Oladele et al. This is an open access article distributed under the Creative Commons Attribution License (CCL), which permits unrestricted use, distribution, and reproduction in any medium, provided the original work is properly cited.

Dates: Received: 09 May 2021; Revised: 12 August 2021; Accepted: 12 September 2021

Keyword: Rainwater harvesting, storage tanks, physical, chemical, bacteriological

Water is a transparent, tasteless, odourless and nearly colourless chemical substance which is the main constituent of earth's stream, lakes and oceans and the fluids of most living organisms. Water is made up of billions of molecules. Each molecules is made up of one oxygen and two hydrogen atoms held together by strong covalent bonds. We have different forms of water on earth which are in gas, solid and liquid states. Water is the world's most precious natural resource. Its uses are innumerable and its importance cannot be overestimated. Its role ranges from domestic uses, agriculture, and industry to religious ceremonies, recreation, landscape decoration and even therapy. Water is basic to life. Despite the obvious need for a sufficient, year-round water supply to sustain life, there is still a lack of water, much less clean water for many of the world's poor. The lack of water is bound to get worse. Estimates of the number of people without water put the number at about one-fifth of the world's population. Rainwater is an important source of fresh water for those who live in both rural and urban areas of developing countries (Ojo, 2016). Rainwater harvesting (RWH) is the collection and storage of rainwater in natural or artificial containers either for immediate use or use before the onset of the next season for domestic, agricultural, industrial and environmental purposes (Kun et al., 2004; Mati et al., 2005; Ubuoh et al., 2016). In spite of the high level of dependence on rainwater for drinking and domestic uses, little is done for monitoring the quality of stored rainwater in cisterns, tanks and other reservoirs receiving rainwater (Achadu et al., 2013).

Studies have shown that the location of sampling points, weather conditions, and industrial, urban or agricultural activities have significant effects on the quality of harvested rainwater (Vazquez et al., 2003 and Meera et al., 2006). The water storage system can also impact the quality of water (Lye, 2002), therefore storage materials needs to be optimized in order to maximize rainwater quality (Adeniyi and Olabanji, 2005). This study aims at assessing the variation of rain water quality with storage time for different coloured storage containers under both indoor and outdoor conditions.

\section{MATERIALS AND METHODS}

Description of Study Area: The study was carried out in the Federal University of Technology, Akure (FUTA). FUTA was founded in 1981. Akure is the capital of Ondo State which was carved out from the old western state. Akure is about 700151 north of equator and 500511 east of meridian. It has an 
approximately 40sqr $\mathrm{mi}$ in area and estimated population of about 484,798 as of 2016 National Population Census. It mean annual temperature ranges from 25-300 and mean annual rainfall ranges from 2500-3500mm (Ojo, 2019).

Colour of Storage Containers and Storage Time: Four coloured plastic storage containers were used under indoor and outdoor conditions. The indoor stored samples were kept within the Water Resources and Environmental Engineering Laboratory of the Department of Civil Engineering, FUTA while the outdoor stored containers were kept outside the school of Engineering and engineering Technology building. The colours of the containers used are black, transparent, ash and green. The water samples were stored for thirty days while samples were taken to the laboratory at intervals of 5 days for laboratory analysis.

Method of Sampling and Collection of Rain Water samples: A random sampling technique was employed in selecting the sample location. Care was taken to ensure that no accidental contaminations occurred during sampling. Sample containers were soaked in acid solution overnight prior to sample collection, followed by proper rinsing with distilled-deionized water and the stored rainwater, before the samples to be analyzed were collected from the storage tanks. A schematic representation of the rainwater harvesting system used in this study is given in Figure 1.

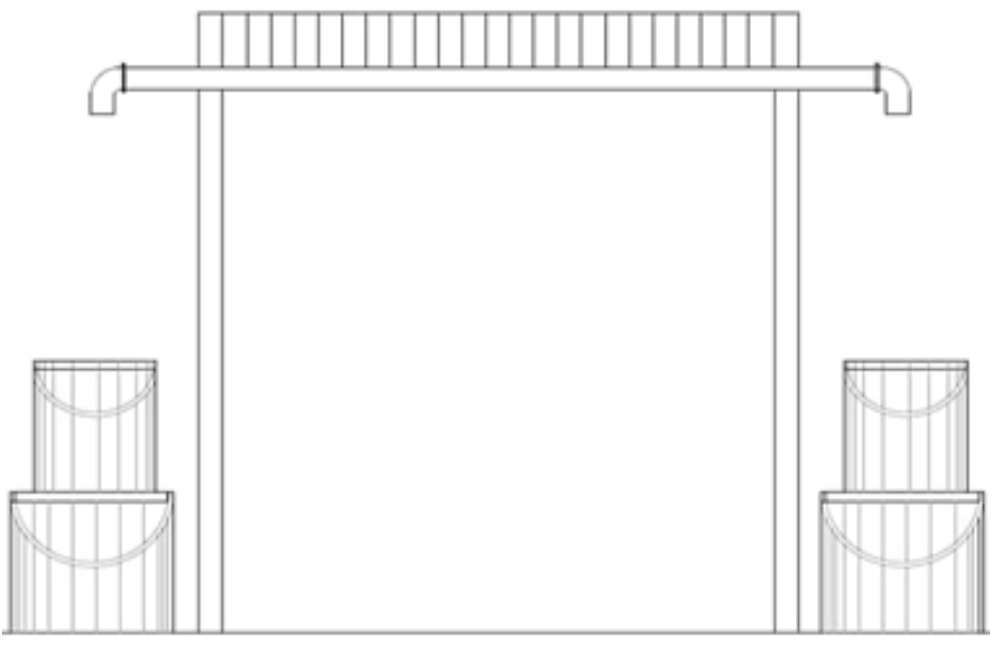

Fig 1: Schematic representation of the rainwater harvesting system

Water Quality Analysis: Determination of appearance of rain water sample: Drinking-water should ideally have no visible colour. Colour in drinking water is usually due to the presence of coloured organic matter (primarily humid and fulvic acids) associated with the humus fraction of soil. Colour is also strongly influenced by the presence of iron and other metals, either as natural impurities or as corrosion products. It may also result from the contamination of the water source with industrial effluents and may be the first indication of a hazardous situation.

Determination of total dissolved solids: The total dissolved solids concentration is the sum of the cations (positively charged) and anions (negatively charged) ions in the water. Therefore, the total dissolved solids tests provides a qualitative measure of the amount of dissolved ions but does not tell us the nature or ion relationships. Therefore the total dissolved solids test is used as an indicator test to determine the general quality of the water.
Determination of $\mathrm{pH}$ : $\mathrm{pH}$ usually has no direct impact on consumers, it is one of the most important operational water quality parameters. It is usually in the range 6.58. For effective disinfection with chlorine, the $\mathrm{pH}$ should preferably be less than 8; however, lower-pH water $.5,10$ ] is likely to be corrosive

The procedure is as follows: Enter the stored program number for the $\mathrm{pH}$ method.

Press PRGM. The display will show: PRGM?

Press: 75 ENTER. The display will show $\mathrm{pH}$ and the ZERO icon

Fill a sample cell with $10 \mathrm{ml}$ of sample (the blank)

Place the blank in the cell holder. Tightly cover the sample cell with the instrument cap.

Press: ZERO. The cursor will move to the right, then the display will show: $6.0 \mathrm{pH}$

Fill another cell with $10 \mathrm{ml}$ of sample

Using a disposable dropper, add $1 \mathrm{ml}$ of phenol red indicator solution to the cell (the prepared sample). Cap the sample cell and invert twice to mix 
Place the prepared sample into the cell holder. Tightly cover the sample cell with the instrument cap.

Press READ. The cursor will move to the right, then the result in $\mathrm{pH}$ units will be displayed

Determination of conductivity: Collect Water Samples from micro catchment location.

Label vials with date, time, location, and collection depth before collecting. Do not put the labels on the vials.

Collect samples by dunking the vials in the waterway. Allow the flow of water to resume before removing each vial and capping it.

Wipe the vials dry and apply the labels.

Allow all water samples to equilibrate to room temperature.

Also equilibrate a distilled or deionized-distilled sample for a control sample.

Before measuring conductivity, follow the manufacturer's directions on establishing a baseline for the conductivity meter. Conductivity is frequently reported in Siemens per meter or microSiemens per meter. If a meter has multiple choices for reported units, use one of these.

For comparison purposes, use a meter to determine the conductivity of distilled or deionized-distilled water. This value will serve as a baseline to compare other measurements to.

Measure the conductance of each water sample using the conductivity meter.

Between samples, wash electrode(s) with clean water and carefully wipe them dry.

If samples contain debris, allow the particles to settle. If a meter has separate electrodes, be sure that they are kept the same distance from either other in each sample and as still as possible

Determination of hardness: Calcium and mag nesium: calmagite colorimetric method

Enter the stored program number for magnesium hardness (as $\left.\mathrm{CaCO}_{3}\right)$.

Press PRGM. The display will show: PRGM?

Press: 30 ENTER. The display will show $\mathrm{mg} / \mathrm{l}, \mathrm{CaCo}_{3}$ and the ZERO icon

Pour $10 \mathrm{ml}$ of sample into a $100 \mathrm{ml}$ graduated mixing cylinder

Add $1.0 \mathrm{ml}$ of calcium and magnesium and calcium test using a $1.0 \mathrm{ml}$ measuring dropper. Stopper inver several times to mix

Pour $10 \mathrm{ml}$ of the solution into each of three sample cells

Add one drop of IMEDTA to one cell (the blank). Swirl to mix

Add one drop of EGTA solution to another cell (the prepared sample) swirl to mix
Place the blank into the cell holder. Tightly cover the sample cell with the instrument cap.

Press: ZERO. The cursor will move to the right, then the display will show: $0.00 \mathrm{mg} / 1 \mathrm{CaCo}_{3}$

Place the prepared sample into the cell holder. Tightly cover the sample cell with the instrument cap

Press: READ. The cursor will move to the right, then the result in $\mathrm{mg} / \mathrm{l}$ magnesium hardness $\mathrm{CaCO}_{3}$ will be displayed

Determination of nitrate: Nitrate concentration above the recommended value of $10 \mathrm{mg} / \mathrm{L}$ is dangerous to pregnant women and poses a serious health threat to infants less than three to six months of age because of its ability to cause methaemoglobinaemia or blue baby syndrome in which blood loses its ability to carry 11,12 sufficient oxygen while Nitrite according to NAFDAC and SON standard should not exceed $0.002 \mathrm{mg} / \mathrm{L}$

Cadmium Reduction Method (Using Powder Pillows or AcciVac Ampuls)

Enter the stored program nuber for high range nitrate nitrogen $\left(\mathrm{NO}_{3}-\mathrm{N}\right)$ powder pillows.

Press PRGM... The display will show: PRGM

Press 51 ENTER. The display will show mg/l, NO3-N and the ZERO icon

Note: For alternate forms $\left(\mathrm{NO}_{3}\right)$, press the CONC key. Fill a sample cell with $10 \mathrm{ml}$ of sample.

Note: Adjust the $\mathrm{pH}$ of stored samples before analysis Press: TIMER ENTER Aone-minute reaction period will begin. Shake the samle vigorously until the timer beeps.

Note: it is important to shake the cell vigorously, shaking time and technique influence color development. For more accurate result, do successive tests on a standard solution and adjust the shaking timer. After the timer beeps the display will show: 5.00 TIMER 2

Press ENTER a five -minute reaction period will begin.

Note: A deposit will remain after the reagent dissolves and will not affect test results.

Note: An amber color will develop if nitrate nitrogen is present to obtain the correct results.

Fill another cell with $10 \mathrm{ml}$ of sample (blank). Wipe off any finger prints or liquid. Place the blank into cell holder. Tightly cover the sample cell with the instrument cap. When the timer beeps, press ZERO. The cursor will move to the right, the the display will show: $0.0 \mathrm{mg} / \mathrm{l} \mathrm{NO} 3-\mathrm{N}$

Note: if reagent Blank Correction is on, the display may flash "limit". Place the prepared sample into the cell holder. Tightly cover the sample cell with the instrument cap. 
Press: READ the cursor will move to the right, then the result in $\mathrm{mg} / \mathrm{l} \mathrm{NO}_{3} \mathrm{~N}$ ( or alternate form) will be displayed.

Note: Use of the standard Adjust Feature for each new lot of reagent is highly recommended. See Acurracy Check.

Note: rins the sample cell immediately aftr use to remove all cadmium particle. Save the spent sample for proper hazardous waste disposal for cadmium.

Determination of sulphate: The range set by NAFDAC, SON, and WHO are $.10100 \mathrm{mg} / \mathrm{L}, 100 \mathrm{mg} / \mathrm{l}$ and $250 \mathrm{mg} / \mathrm{L}$ respectively. The presence of sulphate in drinking-water can cause noticeable taste, and very high levels might cause a laxative effect in unaccustomed consumers. Taste impairment varies with the nature of the associated cation; taste thresholds have been found to range from $250 \mathrm{mg} / \mathrm{litre}$ for sodium sulphate to $1000 \mathrm{mg} / \mathrm{litre}$ for calcium sulphate. It is generally considered that taste impairment is minimal at levels below $250 \mathrm{mg} / \mathrm{litre}$. No health-based guideline value has been derived for sulphate

Sulfa ver 4 method (powder, pillow or Accu Vax Ampuls); USEPA accepted for reporting wastewater analysis using powder pillows

A user-entered calibration is necessary to obtain the most accurate results

Note: the nature of turbidimetric tests reagent requires user calibration for best results. Enter the stored program number for sulphate $\left(\mathrm{SO}_{4}{ }^{2}\right)$. Press PRGM. The display will show: PRGM press 91 enter or the program number selected for a user entered calibration. The display will show $\mathrm{mg} / \mathrm{l}, \mathrm{SO} 4$ and the ZERO icon.

Fill a clean sample with $10 \mathrm{ml}$ of sample

Note: filter highly turbid or coloured samples. Use filtered samples in this step and as the blank

Add the contents of one Sulphate Reagent powder Pillow to the sample cell (the prepared sample). Cap the cell and invert several times to mix.

Note: a while turbidity will develop if sulphate is present in the sample

Note: Accuracy is not affected by undissolved powder Press TIMER ENTER A 5-minute reaction period will begin. Allow the cell to stand undisturbed. After the timer beeps, fill a second sample cell with $10 \mathrm{ml}$ of sample(the blank). Place the blank into the cell holder. Tightly, cover the sample cell with the instrument cap. Press ZERO the cursor will move to the right, then the display will show: $0 \mathrm{mg} / \mathrm{LSO}_{4}$ within five minutes after the timer beeps, place the prepared sample into the cell holder.

Tightly cover the sample cell with the instrument cap. Press READ the cursor will move to the right, then the result in $\mathrm{mg} / \mathrm{l}$ sulphate will be displayed.
Note: if program 91 is used, use of the standard adjust is highly recommended.

Determination of Iron: Procedure for Iron, Ferrous: Enter the stored program number for magnesium ferrous iron $\left(\mathrm{fe}^{3+}\right)$ powder pillows.

Press PRGM. The display will show: PRGM?

Press: 35 ENTER. The display will show mg/l, Fe and the ZERO icon

Fill a sample cell with $25 \mathrm{ml}$ of sample (the blank)

Place the blank into the cell holder. Tightly cover the sample cell with the instrument cap

Press: ZERO. The cursor will move to the right, then the display will show: $0.00 \mathrm{mg} / \mathrm{l} \mathrm{Fe}$

Fill another sample cell with $25 \mathrm{ml}$ of the sample

Add the contents of one ferrous Iron reagent powder pillow to the sample cell (the prepared sample). Swirl the cell to mix

Press; TIMER ENTER. A three-minute reaction will begin

Place the prepared sample into the cell holder, tightly cover the sample cell withe instrument cap.

Press: Read: The cursor will move to the right, the result in $\mathrm{mg} / \mathrm{l}$ ferrous iorn will be displayed

Determination of copper: Procedure Of Test (Copper): Enter the stored program number of bicinchoninate copper (CU) powder pillows. Press PRGM. The display will show: PRGM?

Press 20 ENTER. The display will show $\mathrm{mg} / \mathrm{l}, \mathrm{CU}$ and the ZERO icon.

Fill a sample cell with $10 \mathrm{ml}$ of sample (the blank)

Place the blank into the cell holder. Tightly cover the sample cell with the instrument cap

Press: ZERO. The cursor will move to the right, then the display will show: $0.00 \mathrm{mg} / \mathrm{l} \mathrm{CU}$

Fill another sample cell with $10 \mathrm{ml}$ of the sample

Add the contents of one $\mathrm{Cu}$ Ver 9 copper reagent powder pillow to the sample cell( the prepared sample). Swirl the cell to mix

Press; TIMER ENTER. A two-minute reaction will begin

Within 30 minutes, after the timer beeps, place the prepared sample into the cell holder, tightly cover the sample cell withe instrument cap.

Press: Read: The cursor will move to the right, the result in $\mathrm{mg} / \mathrm{l}$ copper will be displayed.

Determination of phosphorus: Health hazards from algal toxins are primarily associated with overgrowth (bloom) events. Algal blooms may develop rapidly and be of short duration; they are generally seasonal and are frequently associated with the presence of nutrients, particularly phosphate. Groundwater may contain high concentrations of radon and its daughters in areas where bedrock naturally contains high levels 
of radioactivity. This includes areas with granitic rocks, and sediments with phosphate nodules or heavy mineral sand deposits.

The procedure for phosphorus reactive is as follows: Enter the stored program number for reactive phosphorus, ascorbic acid method, press PRGM. The display will show PRGM?

Press: 79 ENTER. The display will show mg/l, PO4 and the ZERO icon.

Fill a sample cell with $10 \mathrm{ml}$ of sample

Add the contents of one phos Ver 3 phosphate powder pillow for $10 \mathrm{ml}$ sample to the cell (the prepared sample). Shake for 15 seconds

Press: TIMER ENTER. A two-minute reaction will begin. Perform step 6-8 during this period.

Fill another sample cell $10 \mathrm{ml}$ of sample (the black)

Place the clank into cell hoder. Tightly cover the sample cell with the instrument cap

Press: ZERO the cursor will move to the right, then the display will show $0.00 \mathrm{mg} / \mathrm{PO} 4$

After the beeps, place the prepared sample into the cell holder. Tightly cover the sample cell with the instrument cap

Press: READ. The cursor will move to the right, then the result in $\mathrm{mh} / \mathrm{l}$ phosphate $\left(\mathrm{PO}_{4}{ }^{3-}\right)$ will be displayed

Determination of total coliform count: Procedure Note: Aseptic technique must be used.

Prepare the required number of tubes of culture medium. The volume and strength (single or double) of medium in the tubes will vary depending on the expected bacteriological density in the water and the dilution series planned. For most surface waters, $10 \mathrm{ml}$ volumes of single-strength medium are appropriate.

Select and prepare a range of sample dilutions; these will normally be suggested by experience. Recommended dilutions for use when there is no experience with samples from that station are given in Table 10.3. To prepare a $1 / 10$ dilution series, mix the sample bottle well. Pipette $10 \mathrm{ml}$ of sample into a dilution bottle containing $90 \mathrm{ml}$ of phosphate-buffered dilution water. To prepare a 1/100 dilution, mix the $1 / 10$ dilution bottle well and pipette $10 \mathrm{ml}$ of its contents into a bottle containing $90 \mathrm{ml}$ of dilution water. Subsequent dilutions are made in a similar way. Alternatively, $1 \mathrm{ml}$ of sample may be added to a bottle containing $9 \mathrm{ml}$ of dilution water.

Pipette the appropriate volumes of sample and diluted sample into the tubes of medium

Label the tubes with the sample reference number, the dilution and the volume of sample (or dilution) added to the tube. Shake gently to mix the sample with the medium. Place the rack in an incubator or water-bath for 48 hours at $35 \pm 0.5^{\circ} \mathrm{C}$ or $37 \pm 0.5^{\circ} \mathrm{C}$.
After 18 or 24 hours, note which tubes show growth. Tubes that show turbidity and gas production, or a colour change indicating the production of acid (if the medium contains a $\mathrm{pH}$ indicator), are regarded as positive. Record the number of positive tubes at each dilution, Return the tubes to the incubator and reexamine after a total of 48 hours of incubation. Continue with the next step of the procedure.

Prepare the required number of tubes of confirmation culture medium (BGLB broth for total coliforms and E. coli medium for faecal coliforms). Using a sterile wire loop, transfer inocula from positive tubes into the confirmation medium. Sterilize the loop between successive transfers by heating in a flame until it is red hot. Allow it to cool before use. If confirmation of both total and faecal coliforms is required, a BGLB and an E. coli medium tube should be inoculated from each presumptive positive. Label these tubes carefully with the same code used in the presumptive test and incubate them for 48 hours at $35 \pm 0.5^{\circ} \mathrm{C}$ or $37 \pm 0.5$ ${ }^{\circ} \mathrm{C}$ for total coliforms (BGLB broth) or for 24 hours at $44 \pm 0.5^{\circ} \mathrm{C}$ for faecal coliforms (E. coli medium).

After the prescribed incubation time, note which tubes show growth with the production of gas, and record the number of positives for each sample dilution.

Compare the pattern of positive results with WHO standards

The physicochemical parameters determined include appearance, temperature, conductivity, $\mathrm{pH}$, total dissolved solid (TDS), chloride, nitrate, phosphate, sulphate, copper and iron. The bacteriological parameter determined was the total coliform count. The temperature and $\mathrm{pH}$ of the rainwater samples were measured immediately after collection. Samples for microbial analysis were kept with a sterilized capped bottle to arrest the further growth of bacterial prior to analysis. The tests were carried out at the Central laboratory of FUTA. The water analyses were done using methods specified in APHA (2005).

\section{RESULTS AND DISCUSSIONS}

Appearance: The appearance of all samples was clears and thus falls within the World Health Organization drinking water standards.

Temperature: Temperature affects the solubility and reaction rates of chemicals. Water temperature exerts a major influence on biological activity and growth, has an effect on water chemistry and can influence water quality measurement. In general, the rate of chemical reactions increases with increasing water temperature. The temperature of the samples for the indoor storage of rain water ranged from $26.2^{\circ} \mathrm{C}$ to $28.90^{\circ} \mathrm{C}$ while the temperature of the samples for the 
outdoor storage of the rain water ranged from $25.90^{\circ} \mathrm{C}$ to $29.10{ }^{\circ} \mathrm{C}$. Figure 2 shows the temperature of the sampled waters. Although the temperature fell within WHO permissible limit of 23 to $40 \mathrm{C}$, the temperature recorded could be said to be suitable for the growth of heterotrophic bacterial species when present in the sample.

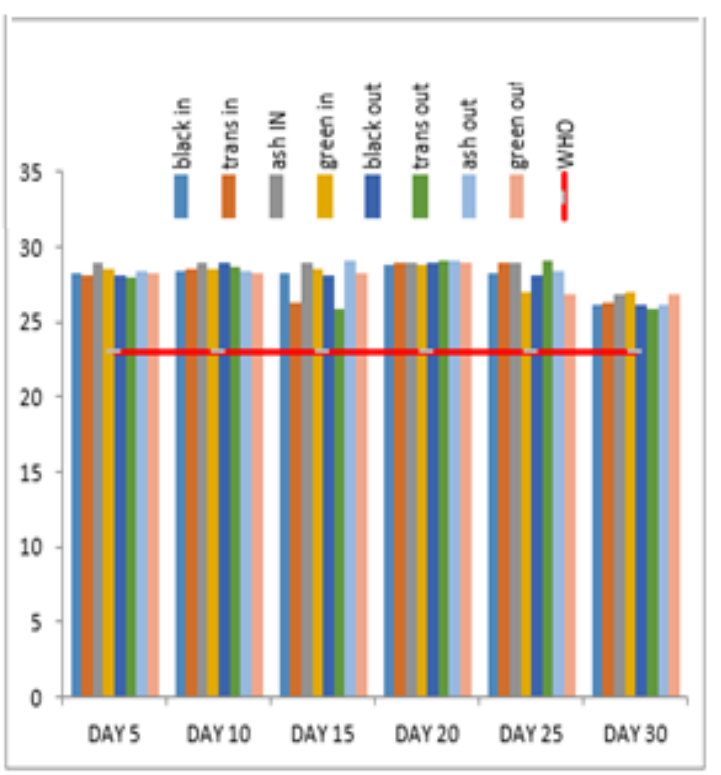

Fig 2: Temperature of the water samples

Conductivity: The Conductivity indicates the presence of dissolved solids and contaminants especially electrolytes confirmed by the presence of cations in water. It is the water's ability to conduct electricity. It is the opposite of resistance. (Environmental, 2010) The conductivity values for the samples range from 18 - $33 \mu \mathrm{s} / \mathrm{cm}$ for the indoor storage a range of $6-45$ $\mu \mathrm{s} / \mathrm{cm}$ was recorded under outdoor conditions.. Figure 3 shows the conductivity values of the sampled water. The results suggests that the mobility of dissolved ions is acceptable in the rain water samples as none of the harvested rainwater samples exceeded the WHO limit of $1000 \mu \mathrm{s} / \mathrm{cm}$.

$p H$ : The $\mathrm{pH}$ of the harvested rainwater of the samples ranged from $5.34-6.73 \mathrm{mg} / \mathrm{l}$ for the indoor storage and $5.28-6.59 \mathrm{mg} / \mathrm{l}$ for the outdoor. The $\mathrm{pH}$ of the water samples did not fall within WHO permissible limit of 6.5 to 8.5 . $\mathrm{pH}$ is regarded as one of the most important indices of water quality because it influences chemical transformations and biological activities in the water. Absolutely neutral precipitation would have a $\mathrm{pH}$ of 7 . The lower mean $\mathrm{pH}$ values can be attributed to wet atmospheric deposition of $\mathrm{CO}_{2}$, $\mathrm{SO}_{2}$ and $\mathrm{NO}_{2}$ produced by vehicular emissions. On its own, however, $\mathrm{pH}$ has no direct effect on human or animal health, but because it is so closely associated with other chemical constituents of water, it is often regarded as having an indirect effect on health (WHO, 2011). Figure 4 shows a graphical representation of the $\mathrm{pH}$.

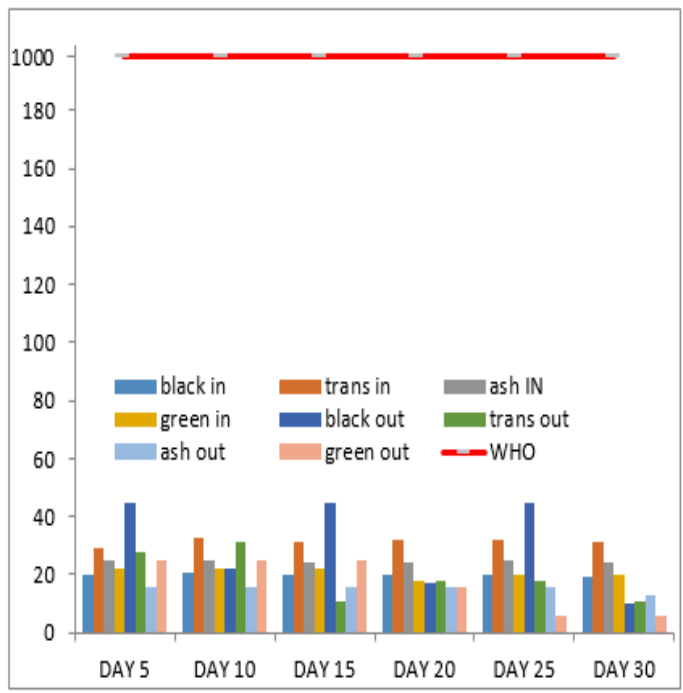

Fig 3: Conductivity of the water samples

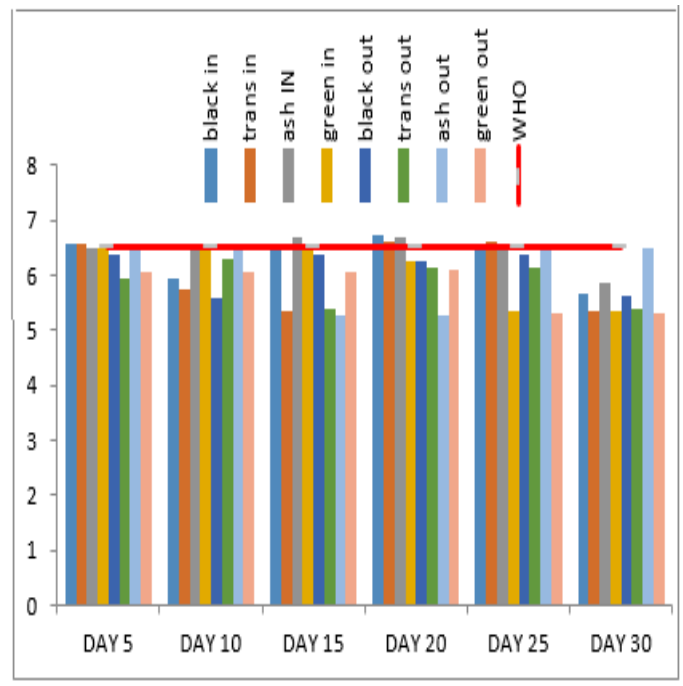

Fig 4: $\mathrm{pH}$ of water samples

Total Dissolved Solids: Total dissolved solids (TDS) combine the sum of all particles that are smaller than 2 microns $(0.0002 \mathrm{~cm})$. This also includes other compounds such as dissolved organic matter (Oram, 2016). The values for total dissolved solids of the samples ranged from $23.6-55.44 \mathrm{mg} / \mathrm{l}$ for the indoor storage location while the value of the total dissolved solids of the samples ranged from $10.08-75.6 \mathrm{mg} / \mathrm{l}$ for the outdoor storage. The results show that $100 \%$ of the rainwater samples fell within WHO permissible limit of $500 \mathrm{mg} / \mathrm{L}$. Figure 5 shows the graphical representation of the total dissolved solids content of the water sample. 


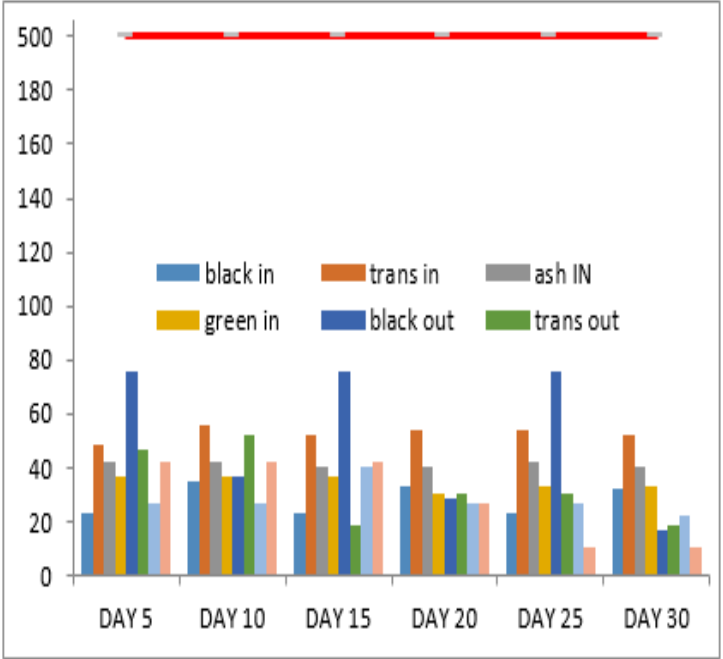

Fig 5: Total dissolved solids content of water samples

Nitrate: Unlike temperature and dissolved oxygen, the presence of nitrates usually does not have a direct effect on aquatic organisms however excess levels of nitrates in water can create conditions that make it difficult for aquatic insects or fish to survive. (TAMU, 2018). The values for nitrates of the samples ranged from ND - $138.8 \mathrm{mg} / \mathrm{l}$ for indoor storage location while the values of the nitrate of the samples for the outdoor storage location ranged from ND $-82.81 \mathrm{mg} / \mathrm{l}$ . High concentration of nitrate above $50 \mathrm{mg} / \mathrm{L}$ in drinking water is deleterious especially to babies due to the formation of methmoglobinamea (WHO, 2004). Figure 6 shows the nitrate values of the sampled waters.

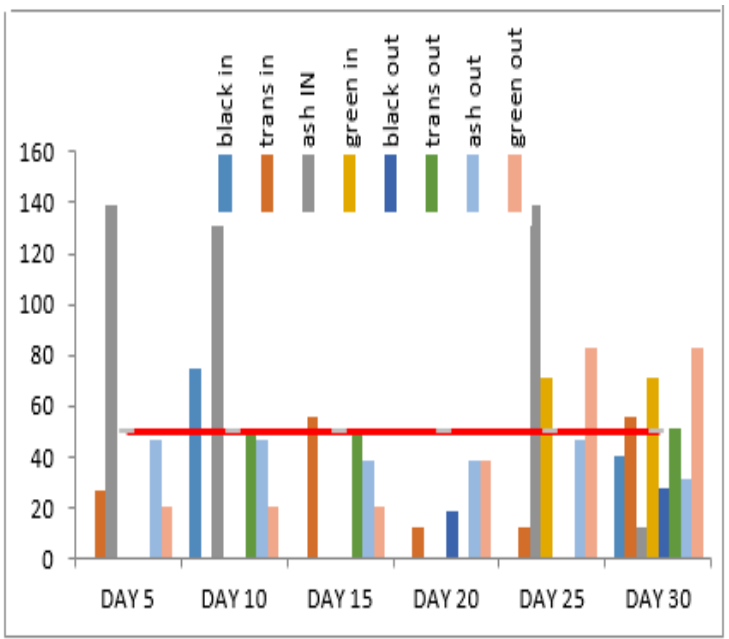

Fig 6: Nitrate content of water samples

Phosphate: Phosphates are chemicals containing the element phosphorus and they affect water quality by causing excessive growth of algae. Excess phosphates create water that is cloudy and low in oxygen (Green,
2016) .The values for the phosphates for the harvested rain water samples ranged from Not Detected (ND) $0.014 \mathrm{mg} / \mathrm{l}$ for the indoor storage while the values for the phosphates for the harvested rain water samples for outdoor storage had phosphate values that ranged from $\mathrm{ND}-0.012 \mathrm{mg} / \mathrm{l}$. All the sampled water had phosphate values that fell within WHO acceptable limits of $0.3 \mathrm{mg} / \mathrm{l}$. High concentration of nitrate above $0.3 \mathrm{mg} / \mathrm{L}$ in drinking water is deleterious especially to babies due to the formation of methmoglobinamea (WHO, 2004). Figure 7 shows the phosphate values of the sampled waters.

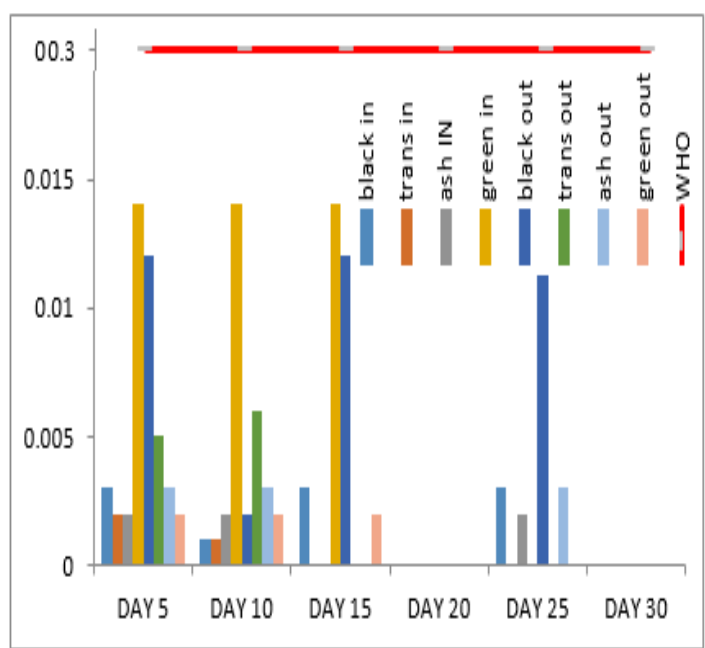

Fig 7: Phosphate content of water samples

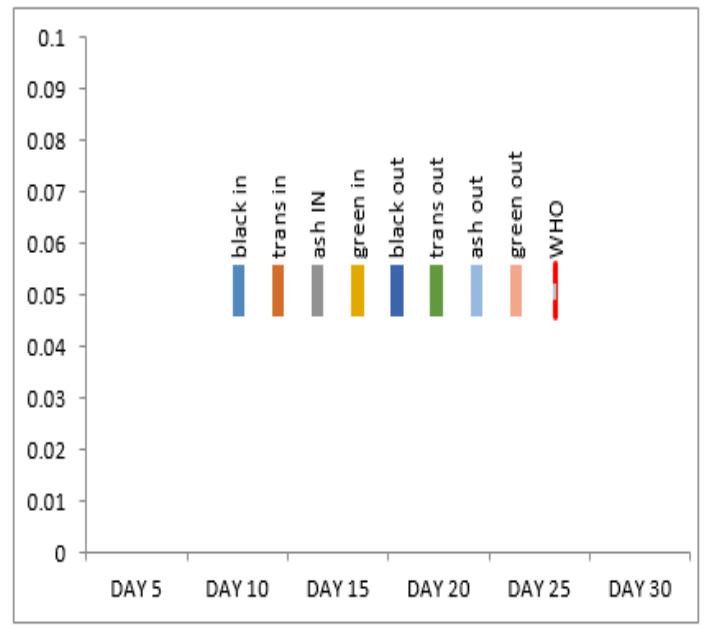

Fig 8: Sulphate content of water samples

Sulphate: Sulphate is one of the major dissolved components of rain water. High concentrations of sulphate in drinking water can have a laxative effect when combined with calcium and magnesium. People not used to drinking water with high level of sulphate can experience dehydration and diarrhea. (LENNTECH, 2019). The values for the sulphate for 
the harvested rain water samples (black, transparent, ash and green) ranges from ND - ND mg/l for the indoor storage while the values for the sulphate for the harvested rain water for outdoor storage ranges from ND - ND mg/l. All the sampled water had sulphate values that fell within WHO acceptable limits of 250 $\mathrm{mg} / \mathrm{L}$. Figure 8 shows the sulphate content of the water samples.

Copper: The values for the copper for the harvested rain water samples (black, transparent, ash and green) ranges from ND $-0.09 \mathrm{mg} / \mathrm{l}$ for the indoor storage while the values for the copper for the harvested rain water samples (black, transparent, ash and green) for outdoor storage ranges from ND $-0.07 \mathrm{mg} / \mathrm{l}$. All the sampled water had sulphate values that fell within WHO acceptable limits $1 \mathrm{mg} / \mathrm{L}$. Figure 9 shows the copper samples of the sampled water.

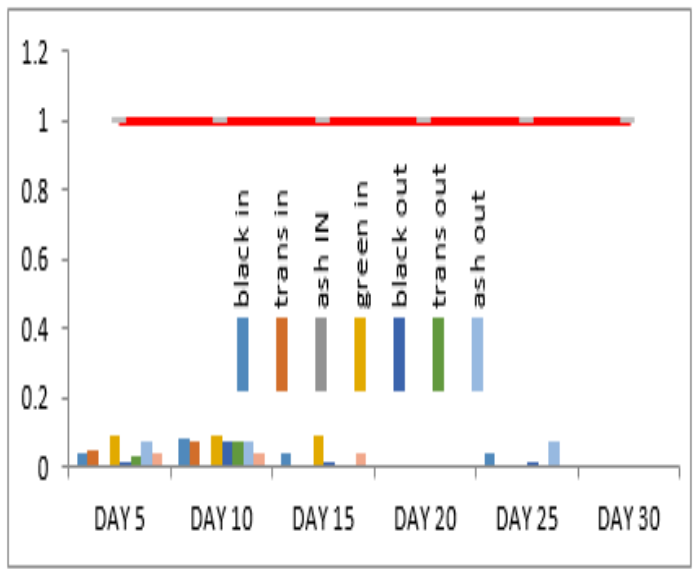

Fig 9: Copper content of water samples

Iron: The values for the Iron for the harvested rain water samples( black, transparent, ash and green) ranges from ND $-0.07 \mathrm{mg} / \mathrm{l}$ for the indoor storage while the values for the iron for the harvested rain water samples (black, transparent, ash and green) for outdoor storage ranges from ND $-0.04 \mathrm{mg} / \mathrm{l}$. All the sampled water had iron values that fell within WHO acceptable limits $0.3 \mathrm{mg} / \mathrm{L}$. Figure 9 shows the iron content of the water samples.

Total Coliform Count: The values for the total coliform count for the harvested rain water samples ranged from 28 - $386 \mathrm{CFU} / \mathrm{ML}$ for the indoor storage while the values for the total coliform count for the harvested rain water samples for outdoor storage ranged from 32 - $303 \mathrm{CFU} / \mathrm{ML}$ The values did not fall within WHO acceptable limits of $0-10 / 100 \mathrm{mg} / \mathrm{L}$. WHO (2011) specified that potable drinking water should be devoid of total coliform in any given sample. Rainwater samples with high total coliform count would most likely have high $e$-coli count. Figure 11 shows total coliform count of the water samples.

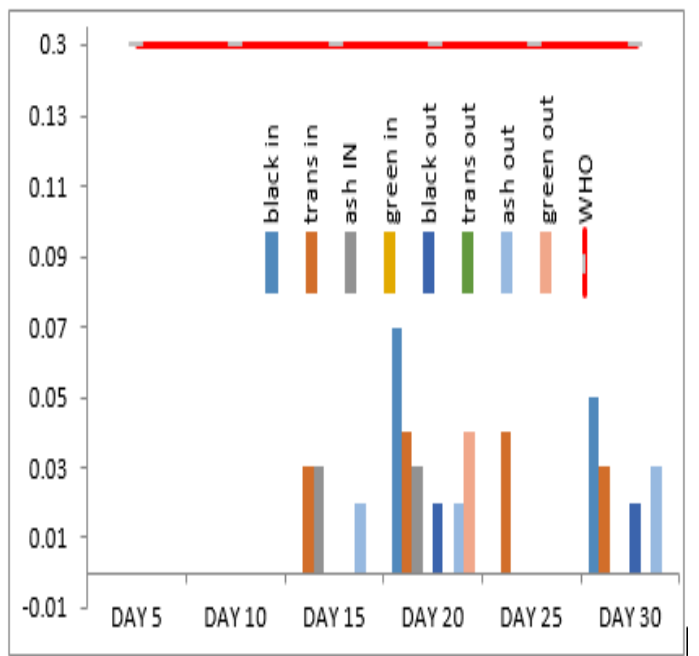

Fig 10: Iron content of the water samples

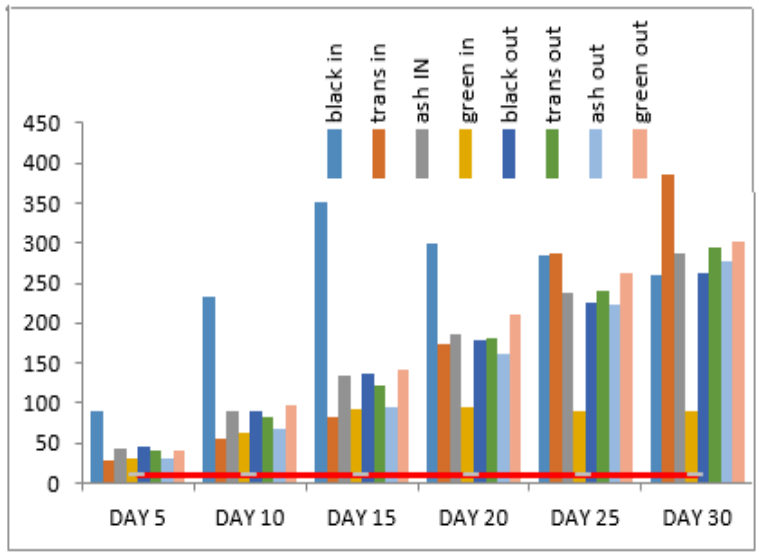

Fig 11: Total coliform count of water samples

Conclusions: Water shortage is one of the critical problems in Akure. Rainwater harvesting is an effective option not only to recharge the groundwater aquifer but also to provide adequate storage of water for future use.This study focuses on the sustainability and effectiveness of a rainwater harvesting system in terms of quality. There was a substantial change in rainwater quality based on the storage location and colour of the container. The study revealed that the indoor storage condition is the most suitable condition with a decrease in concentration of all the parameters evaluated.

\section{REFERENCES}

Achadu, OJ; Ako, FE and Dalla, CL (2013): Quality Assessment of Stored Harvested 
Rainwater in Wukari, North-Eastern Nigeria: Impact of Storage Media. IOSR J. Environ. Sci. Toxicol. Food Tech. 7(5): 25-32

Adeniyi, IF. and Olabanji, IO (2005): The physicochemical and bacteriological quality of rainwater collected over different roofing materials in Ile-Ife, South-western Nigeria. Chem. Ecol. 21(3) (2005):149-166

Environmental, F. (2010). What is conductivity. Retrieved November 11, 2019, from www.fondriest.com

Green, J. (2016). How do phosphates affect water quality. SCIENCING. Retrieved from www.sciencing.com

Kun Z, Linus Z, William H, Mancang L, and Hui C (2004). Quality issues in harvested rainwater in arid and semi-arid Loess Plateau of northern China, J. Arid Environ. 57(4):487-505.

LENNTECH. (2019). Sulphates. LENNTECH B.V, UAE.

Lye, DJ (2002): Health risks associated with consumption of untreated water from household roof catchment systems. J. Am. Water Res.. Assoc. 38(5) (2002), 1301-1306.

Mati BM, Matesu M. and Oduor A. (2005): Promoting rainwater harvesting Eastern and Southern Africa. The Relma experience. World Agroforestry Centre: Kenya.

Meera, V., Mansoor Ahmmed, M. (2006) Water quality of rooftop rainwater harvesting systems: a review, J. Water Supp. Res. Tech. 4: 257268.
Ojo, OM. (2016). Harvested Rainwater Quality: A Case Study of Aule in Akure, South Western Nigeria. Europ. Sci. J. (11):451-462.

Ojo, OM. (2019). Effects of Roofing Materials on Harvested Rain Water Quality. J. Appl. Sci. Environ. Manage. 23 (4): 729-732

Oram, B. (2016). Water Testing Total Dissolved Solids Drinking Water Quality. Dallas. Retrieved 11 11, 2019, from www.waterresearch.net

TAMU (2018). Measuring nitrates and their effects on water quality. TAMU. Retrieved 11 11, 2019, from www.peer.tamu.edu

Ubuoh EA., Ikwa LO and Ogbuji, SI (2016). Quality Determinations of Harvested Rainwater in Selected Storage Tanks in Owerri, South-Eastern Nigeria Inter. Environ. Chem. Ecotoxicol. Res. 1(3): 11-19.

Vazquez A., Costoya M., Pena RM., Garca S. and Herrero C. (2003), A rainwater quality monitoring network: a preliminary study of the composition of rainwater in Galicia, Chemosphere, 51(5): 375386.

World Health Organization (WHO). (2004). Water, sanitation and hygiene links to health. Available online

at http//:www.who.int/water_sanitation_health/publi cations/facts2004/en/print.html.

WHO (World Health Organization. (2011). Guidelines for Drinking-Water Quality (4th ed.). Geneva, Switzerland. 